\title{
Paradigma Critical Theory et al: Tinjauan Terhadap Perda Jawa Timur Nomor 6 Tahun 2014 tentang Pengendalian, Pengawasan, dan Peredaran Minuman Beralkohol
}

\author{
Bagas Heradhyaksa, ${ }^{1}$ Rizqon Halal Syah Aji ${ }^{2}$ \\ ${ }^{1}$ Fakultas Syaria dan Hukum UIN Walisongo, Semarang \\ ${ }^{2}$ Fakultas Ekonomi dan Bisnis UIN Syarif Hidayatullah, Jakarta \\ doi https://doi.org/10.32507/mizan.v3i2.491
}

\begin{abstract}
s:
The adoption of a legal model in law enforcement practices can be defined empirically as the use of philosophic reasoning values to solve legal challenges based on a belief system. There is also a need for an in-depth study of the value pairs underlying the theory of law, such that each other is not paradoxical. This covers the issue of the Regional Restrictions on alcoholic drinks. The analysis tool used in this thesis is a qualitative method with a legal normative approach from different literatures. The findings of the study reveal that East Java Regional Regulation No. 6 of 2014 on the management, monitoring and sale of alcoholic beverages is unsatisfactory because it still needs reform in different areas in order to comply with norm principles and to establish effective regulations in line with the standards of community, morals and norms. You live in the community.
\end{abstract}

Keywords: Alcoholic consumption, Regional laws, Critical theory

\begin{abstract}
Abstrak:
Adopsi paradigma hukum dalam praktik penegakan hukum (law enforcement) secara empirik dapat dimaknai sebagai penggunaan nilai berfikir filosofis dalam penanggulangan masalah hukum berdasarkan sistem nilai. Oleh karenanya diperlukan analisa mendalam terhadap pasangan nilai yang melingkupi filsafat hukum agar satu sama lain tidak paradoks. Termasuk dalah hal ini permasalah Peraturan Daerah yang berkaitan dengan minuman beralkohol. Metode penelitian yang digunakan dalam penelitian ini adalah Metode Kualitatif dengan pendekatan normatif yuridis dari berbagai literatur. Hasil penelitian menyatakan bahwa perda Jawa Timur Nomor 6 Tahun 2014 tentang pengendalian, pengawasan, dan peredaran minuman beralkohol tidak memuaskan, karena masih memerlukan perbaikan di berbagai aspek untuk dapat mengakomodir nilai norma dan mewujudkan peraturan yang baik sesuai dengan nilai kebudayaan, moral, dan norma yang hidup di masyarakat.
\end{abstract}

Kata Kunci: Minum beralkohol, Peraturan Daerah, Critical theory

\footnotetext{
*Naskah diterima tanggal: 17 Januari 2020, direvisi: 21 Februari 2020, disetujui untuk terbit: 2 Maret 2020.

1 Bagas Heradhyaksa adalah pengajar pada fakultas Syariah dan Hukum UIN Walisongo, Semarang. Email: bagashera@walisongo.ac.id

${ }^{2}$ Rizqon Halal Syah Aji adalah pengajar ilmu ekonomi pembangunan pada fakultas ekonomi dan bisnis UIN Syarif Hidayatullah, Jakarta
} 


\section{A. PENDAHULUAN}

Banyak perbedaan pendapat antara para pakar hukum yang mengatakan bahwa ilmu hukum dan filsafat hukum adalah dua hal yang berbeda. Nalar ilmu pengetahuan yuridis sesungguhnya mempunyai fungsi pokok. Secara teoritik, fungsi pokok pengetahuan yuridis adalah menafsirkan undang-undang. Selain itu pengetahuan yuridis juga mempunyai kaidahnya dalam menkontruksi alasan-alasan hukum yang menjadi pijakan keyakinan sosial dalam kehidupan. Legitimasi fungsi dan susunan hukum merupakan aspek fundamental yang berhulu pada filsafat. Sehingga konsep dasar pengetahuan hukum, tidak bisa lepas dari fungsi-fungsi filosofis ${ }^{3}$. Hal ini didasari dari konsep J. Artur Thompson dalam bukunya "An Introduction to Science." Thomson merumuskan bahwa ilmu adalah deskripsi total dan konsisten dari fakta-fakta empiris yang dirumuskan secara bertanggungjawab dalam istilah-itilah sesederhana mungkin. Jelas hukum sebagai ilmu pengetahuan tidak lepas dari tinjauan ilmu filsafat dalam menyelesaikan suatu masalah. Pemikiran dan nilai filosofis sangat perlu untuk menjadi pertimbangan dalam pengambilan keputusan hukum.

Filsafat bukanlah bentuk pemikiran pertama manusia. Sebelum pemikiran filosofi terbentuk, didahului oleh suatu bentuk pemikiran lain yang belum sampai pada pengungkapan teoritis yang dapat dipahami oleh nalar manusia. Ini merupakan dogma atau nilai-nilai yang tumbuh dari manusia secara kodrati dalam cerita kehidupan, seperti baik dan buruk, asal dan tujuan suatu benda, jiwa dan raga, Tuhan dan manusia.

Filsafat secara terminologi berarti "suka kepada kebijaksanaan". N. Driyarkara S.Y mendefiniskan filsafat yakni bermakna pikiran-pikiran manusia yang radikal, dengan mengesampingkan pendirian dan pendapat yang diterima saja, melainkan mencoba memperlihatkan pandangan yang merupakan akar dari banyak pandangan bersikap praktis. ${ }^{5}$ Sedangkan filsafat hukum ialah filsafat tentang segala sesuatu di bidang hukum secara mendalam dan sistematis. Dengan demikian, maka dapat dipahami makna filsafat hukum yang merupakan bagian dari filsafat ilmu yang di dalamnya mempelajari esensi pemikiran manusia. Sebagai hasil dari perkembangan pemikiran manusia, maka filsafat hukum berakibat mempunyai banyak aliran atau mazhab. Untuk dapat memahami sejauh mana perbedaan yang terjadi antara mazhab satu dengan lainnya, maka diperlukan kajian paradigmatik ${ }^{6}$.

Friedmann mengemukakan bahwa filsafat hukum berada di antara filsafat dan teori politik. Tidak sedikit produk hukum mengalami antinomi dalam disiplin kaedah hukum itu sendiri. Pada problematika seperti inilah diperlukan fungsi filsafat hukum untuk berperan memberikan kontribusi nilai intelektual dan cita-cita keadilan dari perspektif teori politik. Filsafat hukum memberikan kontribusi dalam perumusan cita-

${ }^{3}$ D.F Scheltens, Pengantar Filsafat Hukum, ( Jakarta: Erlangga, 1984), hlm 19.

${ }^{4}$ Rizqon H. Syah A \& Nur Rohim Yunus, Filsafat Manusia dalam Dimensi Transadental, (Bogor: Pustaka Pena Ilahi, 2014), hlm 5.

5 ibid

${ }^{6}$ Erlyn Indarti, Diskresi dan Paradigma : Sebuah Telaah Filsafat Hukum, (Semarang : Badan Penerbit UNDIP, 2010), hlm 7. 
cita politik dalam bentuk asas-asas hukum, dalam usaha menjawab problematika hidup, sebab nilai-nilai filsafat hukum melingkupi nilai dasar kehidupan manusia. ${ }^{7}$

Hukum tidak bergerak sendiri, melainkan memerlukan alat kelengkapan ilmu hukum. Penegak hukum merupakan simbol dan kelengkapan pelaksanaan ilmu hukum. Jika lembaga penegak hukum merupakan alat kelengkapan ilmu hukum maka tidak dapat dipisahkan dari pemikiran filsafat hukum. Implikasinya adalah dalam menjalankan fungsinya, lembaga penegak hukum harus menggunakan pemikiran filsafat hukum. Sehingga tidak hanya berpegang kepada undang-undang semata sebagai pijakan hukum, sebab tafsir atas suatu undang-undang semestinya memerlukan pisau analisis pemikiran berdasarkan filsafat hukum.

Sebagai kelengkapan ilmu hukum, lembaga penegak hukum tidak bekerja tanpa bantuan dari perspektif ilmu lain di luar ilmu hukum. Praktik lembaga penegak hukum harus bekerja di tengah masyarakat yang melibatkan ekologi manusia pada peran sosial manusia. Oleh karenanya ada hal-hal yang patut diperhatikan. Pertama; lembaga penegak hukum dalam bekerja menggali dan memperoleh fakta hukum bersumber dari ekologi masyarakat (baik berupa manusia dan sumber lainnya), sehingga dalam bekerja perlu memperhatikan kondisi sosial ekologi yang cermat, namun juga perlu perhitungan secara matang dalam efektivitas kerja. ${ }^{8}$

Dari sudut pandang paradigma hukum, Guba dan Lincoln menawarkan empat pengertian paradigma untuk gejala hukum. Empat paradigma tersebut adalah positivisme, postpositivisme, critical theory et al, dan kontruktivisme. Pada artikel ini untuk meninjau peraturan daerah (PERDA) nomor 6 provinsi Jawa Timur tentang pengendalian, pengawasan, dan peredaran minuman digunakan sebuah teori, bagaimanakah critical theory et al dapat bekerja sebagai fungsi paradigma dalam meninjau filosofi peraturan daerah tersebut.

Paradigma hukum critical theory et al berfungsi sebagai tinjauan kritis terhadap kemapanan semu dalam rangka mentransformasi struktur sosial, politik, kultural, ekonomi, etnis dan gender yang membatasi dan mengeksploitasi masyarakat. ${ }^{9}$ Paradigma hukum dari sisi filosofi hukum critical theory et al, merupakan rangkaian wawasan struktural historis tentang hukum yang bertransformasi tatkala ketidaktahuan dan kesalahpahaman telah tergantikan oleh wawasan hukum yang lebih kaya informasi melalui interaksi dialektis. ${ }^{10}$ Ditinjau dari latar belakang artikel ini, tema pada artikel ini sangat penting sebagai upaya memperkaya literatur pada upaya meninjau produk hukum secara filosofis, agar setiap produk hukum dapat menjadi pijakan hukum yang lebih humanis dan bekerja secara adil di tengah masyarakat.

\footnotetext{
${ }^{7}$ Purnadi P dan Soerjono S, Renungan Tentang Filsafat Hukum, (Jakarta : Rajawali, 1980), hlm 22.

${ }^{8}$ Satjipto Rahardjo, Penegakan Hukum, (Yogyakarta : Genta Publishing, 2009), hlm 20.

${ }^{9}$ Erlyn Indarti, Diskresi dan Paradigma: Sebuah Telaah Filsafat Hukum, (Semarang : Badan Penerbit UNDIP, 2010), hlm 29

${ }^{10}$ Ibid.
} 


\section{B. METODE PENELITIAN}

Penelitian ini menggunakan metode penelitian hukum normatif. Penelitian hukum normatif ialah penelitian yang menggambarkan secara sistematis aturan yang mengatur suatu klasifikasi hukum tertentu, menganalisa hubungan antara peraturan dan menjelaskan permasalahan, serta memprediksi suatu konsepsi untuk di masa yang akan datang. ${ }^{11}$

\section{ANALISIS DAN PEMBAHASAN}

\section{Mengenal Paradigma Hukum}

Guba dan Lincoln memberikan garis keilmuan tentang tiga cabang filsafat yakni epistemologis, ontologis, dan metodologis. Sebelum membahas lebih jauh mengenai paradigma hukum, terlebih dahulu membedah cabang filsafat yakni ontologis, epistemologis dan metodologisnya, ada baiknya akan dijelaskan apa yang dimaksud dengan epistemologi ontologi dan metodologi.

Epistemologis berasal dari bahasa Yunani episteme yang berarti pengetahuan dan logos yang berarti perkataan. Kata "episteme" sendiri berasal dari kata "epistamai" yang artinya mendudukan. Maka kata "episteme" dapat diartikan "pengetahuan sebagai upaya intelektual untuk mendapatkan sesuatu dalam kedudukan setepatnya. Berdasarkan etimologi kata epistemologi tersebut, dapat dikatakan bahwa epistemologi adalah ilmu tentang pengetahuan manusia atau sering disebut juga sebagai teori pengetahuan. ${ }^{12}$ Paradigma positivistik menilai epistemologi adalah dualistis objektif. Maksudnya adalah penganut atau pemegang objek observasi atau investigasi pada dua entity independen. Dua entity independen berarti bebas nilai, bebas bias dan mempunyai prosedur ketat atas temuan berulang berarti benar.

Ontologi berasal dari bahasa Yunani. "on" atau "ontos" berarti "ada", dan "logos" berarti "ilmu". Pemaknaan "ontologi" secara utuh adalah ilmu tentang yang ada. Sedangkan menurut istilah ontologi adalah ilmu yang membahas tentang hakikat yang ada, yang merupakan ultimate reality baik yang berbentuk jasmani (nyata) maupun rohani (abstrak). Soetriono dan Hanafie menjelaskan bahwa ontologi merupakan azas dalam menerapkan batas atau ruang lingkup wujud yang menjadi obyek penelaahan (obyek ontologis atau obyek formal dari pengetahuan). Ontologi juga penafsiran tentang hakikat realita (metafisika) dari obyek ontologi atau obyek formal. ontologi dapat merupakan landasan ilmu yang menanyakan apa yang dikaji oleh pengetahuan dan biasanya berkaitan dengan alam kenyataan dan keberadaan.

Paradigma positivisme menjelaskan ontologi sebagai realisme naif. Maksud "realisme naif" adalah suatu sifat dari realita eksternal, objektif, real dan dapat dipahami. Realisme naif juga bersifat general, bebas konteks, hukum sebab akibat, reduksionis dan deterministik. Postpositivisme menjelaskan ontologi sebagai realisme kritis. Ontologi pada lingkup realisme eksternal, objektif dan real bisa saja dapat

\footnotetext{
${ }^{11}$ Peter Mahmud Marzuki, Penelitian Hukum, (Jakarta: Prenadamedia Group, 2016), h. 32.

${ }^{12}$ Hyronimus Rhiti, Filsafat Hukum, (Yogyakarta : Univ Atma Jaya, 2011), hlm 202.
} 
dipahami tetapi tidak sempurna karena keterbatasan mekanisme intelektual manusia. Ontologi mengenal modifikasi dualis atau objektivis. Dapat dimaknai dualisme surut dan objektivitas menjadi kriteria penentu. Eksternal objektif merupakan kesesuaian antara pengetahuan yang ada dibanding dengan komunitas ilmiah kritis. Pada ekternal objektif artinya suatu fakta temuan yang terjadi berulang berarti "barangkali benar" (aproksimasi).

Dari sisi paradigma konstruktivisme, ontologi bersifat relativisme yang berarti bahwa realitas majemuk dan beragam, berdasarkan pengalaman sosial-individual, lokal, dan spesifik. Pemaknaan atas 'konstruksi' mental atau intelektualitas manusia, bentuk dan isi terpulang pada penganut atau pemegang sehingga dapat berubah menjadi informed dan atau sophisticated humanis.

Metodologi berasal dari bahasa Yunani "metodos" dan "logos". Kata "metodos" terdiri dari dua suku kata yaitu "metha" yang berarti melalui atau melewati dan "hodos" yang berarti jalan atau cara. Metode berarti suatu jalan yang dilalui untuk mencapai tujuan. "logos" artinya ilmu. Metodologi adalah ilmu-ilmu atau cara yang digunakan untuk memperoleh kebenaran menggunakan penelusuran dengan tata cara tertentu dalam menemukan kebenaran, tergantung dari realitas yang sedang dikaji.

Metodologi dari paradigma positivisme adalah eksperimental atau manipulatif, maksudnya adalah uji empiris dan verifikasi research question dan hipotesis, manipulasi dan kontrol terhadap kondisi berlawanan, utamanya metode kuantitatif. Metodologi adalah modifikasi eksperimental atau manipulatif, artinya adalah falsifikasi dengan cara critical multiplism atau modifikasi 'trianggulasi', utilisasi teknik kualitatif, setting lebih natural, informasi lebih situasional, dan cara pandang emic.

Dari sisi paradigma konstruktivisme, metodologi adalah hermeneutika atau dialektikal, maksudnya adalah 'konstruksi' ditelusuri melalui interaksi antar dan sesama penganut atau pemegang dan obyek observasi atau investigasi, dengan teknik hermeneutikal dan pertukaran dialektikal 'konstruksi' tersebut dapat diinterpretasi, dibandingkan dan ditandingkan. Tujuannya adalah mendestilasi konstruksi pada aspek konsensus atau 'konstruksi' resultante.

Sebagai upaya mempertajam teori hukum, paradigma hukum merupakan pinjakan yang harus dilalui. Ada pendapat beberapa ahli hukum tentang paradigma. Pendapat Wignjosoebroto, memberikan arti bahwa paradigma adalah "pola atau model berfikir. Pola berpikir akan memberikan cara pandang objek hukum, sehingga melahirkan persepsi interpretatif dan berakhir pada sebuah kesimpulan dan pandangan hukum. ${ }^{13}$

Pendapat lain tentang paradigma, dikemukakan oleh Indarti. Menurutnya paradigma pandang sebagai keseluruhan konsep yang diterima oleh sebagian besar anggota suatu komunitas intelektual sebagai sebuah ilmu pengetahuan, sebab paradigma dapat menjelaskan suatu proses, ide, atau sekumpulan data yang kompleks.

${ }^{13}$ Soetandyo Wignjosoebroto, Pergeseran Paradigma dalam Kajian Sosial dan Hukum, (Malang : Setara Press, 2013), hlm. 8 
Pendapat tersebut bermakna bahwa paradigma dapat membantu memecahkan masalah. ${ }^{14}$

Pada paradigma kontruktivisme, epistemologi mempunyai sifat transaksional atau subyektivis. Maksudnya adalah penganut obyek observasi atau investigasi terkait secara interaktif. Ketika temuan dimediasi oleh nilai yang berpegang oleh semua pihak terkait dan terjadi fusi antara ontologi dan epistemologi. Sedangkan dari sisi ontologi realisme historis, critical theory et al berarti realitas virtual yang terbentuk oleh faktor sosial, politik, budaya, ekonomi, etnis, dan gender. Semua faktor tersebut akan sejalan dengan waktu yang terkristalisasi dan dianggap real. Terakhir adalah paradigma kontruktivisme dari aspek metodologi yang merupakan dialogis atau dialektikal, maksudnya adalah ada dialog antara penganut atau pemegang dengan obyek observasi atau investigasi secara dialektikal, mentransform kemasabodohan dan kesalahpahaman menjadi kesadaran bahwa struktur historis dapat diubah dan karenanya diperlukan aksi nyata.

\section{Paradigma Critical Theory et al}

Pada aliran filsafat hukum critical legal theory, critical legal studies dan feminist jurisprudence meyakini hukum secara virtual atau sejarah. Implikasi dari pemahaman atas keyakinan tersebut adalah serangkaian struktur sebagai suatu realitas virtual atau historis. Realitas virtual merupakan hasil proses panjang dari kristalisasi dari nilai-nilai politik, ekonomi, sosial, budaya, etnik, gender, dan agama. Pada saat bersamaan, hukum adalah instrumen hegemoni yang cenderung dominan, diskriminatif dan eksploitatif. Konsekuensinya hukum akan terbuka bagi kritik, revisi, dan transformasi guna menuju emansipasi ${ }^{15}$.

Penjelasan tersebut dapat dipahami jika kelompok aliran ini mengusung etika secara intrinsik dengan visi pencerahan moral, maka bersifat value bounded atau mengakui adanya penghargaan terhadap nilai. Penggunaan ukuran-ukuran tersebut dapat dipahami jika para pakar hukum, praktisi hukum maupun pemerhati hukum yang menganut aliran critical theory et al, berlaku sebagai instigator sekaligus fasilitator perubahan, transformative intellectual, penyedia advokasi dan aktivis. Untuk merengkuh aliran-aliran ini, diperlukan pelatihan resosialisasi, tradisi penelitian kualitatif yang didukung kuantitatif, sejarah, nilai-nilai altruism, serta pemberdayaan masyarakat.

Critical legal studies merupakan arus pemikiran hukum yang mencoba menentang paradigma liberal yang melekat kuat dalam studi hukum (jurisprudence) di Amerika melalui metodenya yang dikenal dengan metode dekonstruksi. Dekonstruksi dalam hukum merupakan strategi pembalikan, yang berfungsi melihat makna istilah yang tersembunyi. Istilah dekontruksi cenderung diistimewakan melalui sejarah, meski dekonstruksi itu sendiri tetap berada pada hubungan istilah/wacana.

${ }^{14}$ Erlyn Indarti, Diskresi dan Paradigma : Sebuah Telaah Filsafat Hukum, (Semarang : Badan Penerbit UNDIP, 2010), hlm 14.

${ }^{15} \mathrm{Ibid}$, hlm 27. 
Critical legal studies memberikan argumentasi akademik tentang proses hukum, seperti pembentukan undang-undang maupun proses penafsiran. Critical legal studies menjelaskan bahwa tidak mungkin proses hukum berlangsung dalam konteks bebas atau netral dari pengaruh moral, agama, dan pluralisme politik. Artinya aliran ini menegaskan bahwa tidak mungkin mengisolasi hukum dari konteks dimana hukum tersebut eksis. ${ }^{16}$ Sedangkan feminisme jurisprudence melihat bahwa hukum pada dasarnya memiliki sejumlah keterbatasan untuk merealisasikan nilai-nilai sosial. Pembentukan hukum; baik pembentukan aturan, maupun substansinya bersifat phallocentris. Pemaknaan sifat phallocentris yaitu lebih memihak kepentingan laki-laki, sehingga hukum berjalan untuk kepentingan status quo. Feminisme dalam hukum juga menolak bagaimana posisi wanita senantiasa dimarjinalkan dalam perjanjian, pekerjaan, dan berbagai kehidupan sosial. Kaum feminis meilhat bahwa sekalipun para wanita telah berusaha untuk memperbaiki masa depannya, namun tetap saja hukum selalu dibayang-bayangi oleh ideologi yang lebih maskulin.

\section{Deskripsi Kasus}

Dikutip dari jawapos.com ${ }^{17}$, dilaporkan bahwa setelah melalui sejumlah kontroversi, rancangan peraturan daerah (RAPERDA) tentang pengendalian, pengawasan, dan peredaran minuman beralkohol akhirnya resmi disahkan menjadi perda dalam sidang paripurna Dewan Perwakilan Rakyat Daerah (DPRD) Provinsi Jawa Timur pada hari selasa 22 Juli 2014. Seluruh elemen pemerintah daerah Jawa Timur secara bulat mendukung raperda tersebut. Gubernur Jatim Soekarwo menyatakan, perda itu sangat penting untuk meminimalkan dampak buruk minuman beralkohol atau minuman keras (miras). Pertimbangan hukum dan politik dari pengesahan peraturan daerah tersebut di dorong oleh pertimbangan ketertiban umum. Pemerintah provinsi Jawa memberikan pertimbangan atas berbagai macam masalah kriminalitas selama dua tahun terakhir yang disebabkan oleh minuman keras.

Dari pertimbangan politik, DPRD Jawa Timur pun mendukung bahwa perda tersebut berlaku sehingga mengikat kepada pengusaha, elemen masyarakat, dan seluruh pemerintah kota maupun kabupaten pada geopolitik pemerintah di Jawa Timur. Dari fakta hukum tersebut, pemerintah provinsi ikut mengendalikan serta mengontrol produksi dan peredaran minuman keras sehingga tidak meluas. Larangan dalam perda tersebut juga cukup ketat, yakni larangan menjual atau memproduksi minuman keras kepada anak di bawah umur yang kadar dan kualitas minuman beralkoholnya tidak memenuhi standar. Jika melanggar perda tersebut, maka pemerintah provinsi dapat mengenakan sanksi dengan cara pencabutan sekaligus sanksi pidana.

\section{Minuman Keras dalam Masyarakat Indonesia}

Minuman keras adalah minuman yang oleh sebagian besar masyarakat Indonesia ditentang keberadaannya. Bukan saja karena tidak sesuai dengan norma yang

\footnotetext{
${ }^{16}$ Otje Salman, Filsafat Hukum, (Bandung : Refika Aditama, 2009), hlm 73.

${ }^{17} \mathrm{http} / / / \mathrm{www}$.jawapos.com/baca/artikel/4852/Perda-Miras-Akhirnya-Digedok
} 
hidup di masyarakat, namun juga dampaknya dapat meresahkan masyarakat. Seseorang yang mengkonsumsi minuman keras, mempunyai resiko kehilangan akal sehatnya meskipun hanya beberapa saat. Sehingga ketika kehilangan akal sehat dan berdampak nalarnya rusak, seseorang dapat melakukan tindakan tidak terpuji, bahkan tidak jarang ditemukan hingga melakukan tindak kriminal seperti pembunuhan, pemerkosaan, perusakan dan lain sebagainya. Oleh karena itu, tidak mengherankan jika minuman keras ditentang keberadaannya bagi sebagian besar masyarakat Indonesia, baik di masyarakat yang tingkat modernitasnya sudah tinggi atau yang masih tradisional. Sebagai contohnya, hampir sebagian besar orang tua akan melarang anaknya untuk mengkonsumsi minuman keras dan hampir tidak mungkin ada orang tua yang rela menyuruh anaknya mengkonsumsi minuman keras. Uraian tersebut jelas menjastifikasi bahwa mengkonsumsi minuman keras dianggap hal yang tabu bahkan dilarang.

Sama dengan perbuatan buruk lainnya seperti "kumpul kebo", perzinahan, pencurian dan lain sebagainya, tindakan orang mengkonsumsi minuam keras tidak akan serta merta memperlihatkan kebiasaannya mengkonsumsi minuman keras kepada khalayak umum. Sebab bisa menjadi aib bagi keluarga akibat tindakannya. Hal tersebut tidak terbantahkan lagi, bahwa faktanya semua keluarga di Indonesia akan malu jika ada anggota keluarganya yang berkebiasaan mengkonsumsi minuman keras. Para konsumen minuman keras hanya merasa bangga dengan perbuatannya jika berada dalam komunitasnya sesama konsumen minuman keras. Dengan begitu, dapat diketahui bahwa masyarakat pada umumnya melakukan resistensi pada keberadaan minuman keras.

Menurut Soerjono Soekanto, celaan, penyalahan dan pengucilan adalah salah satu bentuk sanksi sosial dari masyarakat adat. ${ }^{18}$ Dengan begitu dapat diketahui bahwa minuman keras sesungguhnya juga dilarang melalui hukum adat atau hukum yang hidup di masyarakat. Hal tersebut dikarenakan timbulnya rasa malu bagi konsumen minuman keras dan keluarganya atas tindakannya. Rasa malu timbul salah satunya karena khawatir akan mendapat celaan, penyalahan atau pengucilan dari masyarakat.

Satjipto Rahardjo menjelaskan bahwa negeri ini tidak hanya berdasarkan hukum, melainkan juga berdasarkan moral. ${ }^{19}$ Sehingga sesungguhnya pembuatan peraturan daerah mengenai pengendalian, pengawasan, dan peredaran minuman beralkohol adalah suatu langkah yang baik. Pertimbangan tersebut dikarenakan sesuai dengan pertimbangan moral bangsa Indonesia. Adapun sebagian kecil kelompok masyarakat yang mendukung keberadaan minuman keras, tidak bisa dijadikan dasar untuk melegalkan keberadaan minuman keras. Bukan karena jumlah mereka yang sedikit atau minoritas, namun karena apa yang diinginkan oleh mereka bertentangan dengan moral bangsa Indonesia dan bertentangan dengan norma-norma yang hidup di masyarakat.

Jika jumlah mereka sedikit atau minoritas namun apa yang diinginkannya bermanfaat dan tidak bertentangan dengan moral dan norma, maka harus tetap

\footnotetext{
${ }^{18}$ Soerjono Soekanto, Hukum Adat Indonesia, (Jakarta : Rajawali Press, 2011), hlm 78.

${ }^{19}$ Satjipto Rahadrjo, Penegakan Hukum Progresif, (Jakarta : Kompas, 2010) , hlm 254.
} 
dilindungi. Sepeti contohnya, sebagian kecil masyarakat menginginkan agar perzinahan atau seks bebas diperbolehkan namun karena hal tersebut bertentangan dengan moral dan norma yang hidup di masyarakat maka hal tersebut sudah sewajarnya dilarang. Bukan hanya persoalan moral dan norma, karena sesungguhnya mengkonsumsi minuman keras sangat berpotensi merugikan banyak orang. Sama seperti tindak pidana lainnya, pencurian, korupsi, pencucian uang dan lain sebagainya sangat berpotensi untuk merugikan banyak orang sehingga dibuatlah undang-undang yang melarangnya.

\section{Filsafat Hukum sebagai Pertimbangan Pembuatan Perda Pengaturan Miras}

Lili Rasjidi menjelaskan bahwasanya Ilmu Hukum tidak dapat memberikan jawaban yang memuaskan dalam menjawab persoalan hukum. Hal ini dikarenakan bahwa Ilmu Hukum hanya dapat melihat gejala hukum belaka. Ilmu Hukum hanya dapat melihat apa yang dapat dilihat dengan panca indera, bukan melihat dunia hukum yang tak dapat dilihat atau tersembunyi. ${ }^{20}$ Dengan demikian, untuk melihat apakah pembentukan peraturan daerah tentang minuman keras di Jawa Timur merupakan suatu gejala hukum? Dan bagaimana dampaknya, apakah memberikan dampak positif ataukah berdampak negatif? Dalam konteks inilah diperlukan bantuan dari filsafat hukum untuk menerangkannya.

Penggunaan filsafat hukum sebagai perspektif dalam pembentukan peraturan daerah tentang minuman keras bukan hanya berhenti pada aspek struktural saja, akan tetapi tinjauannya juga dari aspek kultural dan substansinya. Tinjauan dari tiga komponen sistem hukum, sesuai pendapat dari Lawrence M Friedman. Selain itu juga dapat di tinjau melalui tiga nilai dasar hukum menurut Gustav Radbruch yaitu keadilan, kepastian hukum dan kegunaan ${ }^{21}$.

Filsafat Hukum bekerja mencari hakikat dari pada hukum dalam menyelidiki kaidah hukum sebagai pertimbangan nilai. ${ }^{22}$ Maka dapat diketahui bahwa peraturan daerah tentang pengendalian, pengawasan, dan peredaran minuman beralkohol sudah memenuhi tiga komponen sistem hukum dan tiga nilai dasar hukum. Hal itu dapat dilihat dari nilai-nilai yang terkandung peraturan daerah tersebut. Peraturan daerah tersebut mempunyai semangat dalam melarang suatu perbuatan yang tidak sesuai dengan nilai dan norma yang berlaku di Indonesia yaitu mengkonsumsi minuman beralkohol. Pertimbangan tersebut sesuai dengan budaya masyarakat Indonesia.

Tentu peraturan daerah tersebut berimplikasi pada regulasi pasar. Para pedagang yang menjadi distributor minuman beralkohol akan memperoleh kerugian. Selain itu para produsen tidak lagi leluasa dalam memproduksi serta menjual produknya. Namun, perspektif tersebut dilihat hanya dari satu sisi saja, yakni sisi produsen dan regulator pasar. Semangat dari peraturan daerah tentang pengendalian, pengawasan, dan peredaran minuman beralkohol adalah melindungi nilai dan norma yang hidup dalam masyarakat Jawa Timur. Sehingga harus terus dipertahankan

\footnotetext{
${ }^{20}$ Lili Rasjidi, Dasar-Dasar Filsafat Hukum, (Bandung : Alumni , 1982), hlm. 2

${ }^{21}$ Satjipto Rahardjo, Ilmu Hukum, (Bandung : Citra Aditya, 2000), hlm 19.

${ }^{22}$ Lili Rasjidi, Dasar-Dasar Filsafat Hukum, (Bandung : Alumni , 1982), hlm 1
} 
keberadaannya untuk menciptakan tatanan masyarakat yang baik sesuai dengan pribadi bangsa Indonesia yang luhur. Sungguh sangat tidak bijaksana jika demi melindungi kepentingan sedikit orang yang tidak mau tunduk pada nilai dan norma masyarakat dan justru berkiblat pada kehidupan bebas (liberal). Jika hal tersebut dibiarkan maka bisa jadi seluruh nilai dan norma yang menjadi ciri khas kepribadian Bangsa Indonesia yang luhur, akan segera punah tergantikan dengan gaya hidup yang serba bebas. Oleh karena itu, perlu kiranya agar perda Jawa Timur Nomor 6 Tahun 2014 tentang pengendalian, pengawasan, dan peredaran minuman beralkohol diperbaiki lagi isi kandungannya agar bukan hanya mengatur peredaran minuman keras namun juga melarang peredaran minuman tersebut.

\section{Tinjauan Paradigma Critical Theory et al terhadap Perda Nomor 6 Tahun 2014}

Paradigma Crtitical theory et al, adalah paradigma yang berangkat dari suatu kecurigaan. Perda Nomor 6 Tahun 2014 memiliki kandungan yang tidak melarang sepenuhnya peredaran minuman beralkohol di Jawa Timur. Sebaliknya, perda ini terkesan justru melegalkan peredaran minuman beralkohol. Pemerintah daerah justru memfasilitasi peredaran minuman beralkohol tersebut. Hal ini dapat dilihat pada pasal 2 ayat 3 dan ayat 4 Perda Nomor 6 Tahun 2014 yang isinya sebagai berikut:

(3) Minuman beralkohol sebagaimana dimaksud pada ayat (2) ditetapkan sebagai barangdalam pengawasan yang jumlah dan peredarannya dibatasi.

(4) Pengawasan sebagaimana dimaksud pada ayat (4) meliputi pengawasan terhadap pengadaan, peredaran, dan penjualannya.

Bunyi pasal tersebut pada akhirnya dapat diinterpretasikan bahwa peredaran minuman beralkohol tetap diperbolehkan dijual-belikan. Adapun pemerintah hanya berfungsi untuk mengawasi peredarannya, bukan melarangnya. Menurut paradigma critical theory et al, pertimbangan faktor sosial, politik, budaya, ekonomi, etnis dan gender dengan jalannya waktu akan mengkristal dan akan dianggap real. Dengan pertimbangan faktor sosial yang menganggap bahwa minuman beralkohol adalah minuman yang tidak pantas dikonsumsi menjadi sesuatu yang real. Dari perspektif kebudayaan Bangsa Indonesia yang menganggap bahwa aktivitas mengkonsumsi minuman beralkohol adalah sesuatu yang tabu dapat dianggap kebenarannya. Apalagi ditambah dengan label bahwa Jawa Timur adalah salah satu pusat pendidikan keagamaan di Indonesia, dimana semua agama juga melarang mengkonsumsi minuman keras. Semestinya faktor kultural tersebut dianggap real karena sudah mengendap lama di masyarakat.

Dari uraian di atas, dapat diketahui bahwa nilai dan norma yang hidup di masyarakat, sepantasnya dianggap sebagai sesuatu yang real, tidak sesuai dengan perda Jawa Timur Nomor 6 Tahun 2014 yang hanya mengatur peredaran minuman beralkohol bukan melarangnya. Dengan demikian, maka seharusnya ada upaya dari seluruh elemen masyarakat untuk dapat berdialog kepada pihak pemerintah supaya dapat mengakomodasi nilai dan norma yang hidup dimasyarakat dalam menentang keberadaan minuman beralkohol. Diharapkan dengan dialog-dialog yang terjadi, akan terciptalah peraturan yang jauh lebih baik lagi. Peraturan yang secara struktural tidak 
memberikan kesempatan lagi bagi beredarnya minuman beralkohol. Sehingga substansi dari peraturan tersebut benar-benar melarang peredaran minuman beralkohol, bukan hanya menciptakan peraturan yang seakan-akan melarang tentang peredaran minuman beralkohol namun isinya justru mengatur tentang peredaran minuman beralkohol bahkan pemerintah terkesan memfasilitasi peredarannya.

Menurut Nozick, hukum kriminal diperlukan demi mencegah orang melakukan perbuatan jahat terhadap yang lain. Selain itu, umum diterima bahwa hukum kriminal diperlukan untuk mencegah perilaku yang secara serius mengancam atau membahayakan. ${ }^{23}$ Dengan begitu, maka tidak mengherankan jika aktivitas peredaran minuman keras dapat dilarang seutuhnya atau bahkan dimasukan dalam tindakan kriminal. Hal tersebut dikarenakan minuman keras dapat mengancam dan membahayakan masyarakat umum.

Pemahaman realisme historis terbentuk dari resistensi terhadap keberadaan minuman keras. Bukan semata-mata faktor yang bersifat immateriil seperti budaya, nilai dan norma, politik dan lain sebagainya. Namun masyarakat juga diresahkan oleh banyaknya kasus kematian yang diakibatkan oleh pengkonsumsian minuman beralkohol. Masyarakat tidak mau jika anggota keluarga mereka, suatu saat menjadi salah satu korban dari kebiasaan mengkonsumsi minuman beralkohol. Sebagai contoh kejadian di Kabupaten Mojokerto, sebanyak 17 orang meninggal setelah mengkonsumsi minuman beralkohol. Kasus yang sama seperti itu pun pernah terjadi di Malang dengan menewaskan 9 orang. Rangkaian kejadian demi kejadian berlanjut seperti di Surabaya menyebabkan jatuh korban tewas hingga 11 orang. Begitu juga di Kabupaten Gresik, menewaskan 3 orang dan juga di Blitar menewaskan 16 orang. Rangkaian kejadian itu kiranya sudah menjadikan fakta serius, jika minuman keras adalah musuh bersama umat manusia. Selain dapat merusak moral, juga dapat merusak kesehatan bahkan tidak jarang berujung kepada kematian. Dengan demikian, tidak ada yang salah dengan nilainilai kebudayaan luhur Bangsa Indonesia yang menolak keberadaan dan konsumsi minuman beralkohol.

\section{KESIMPULAN}

Melalui kacamata paradigma critical theory et al, dapat diketahui bahwa perda Jawa Timur Nomor 6 Tahun 2014 tentang pengendalian, pengawasan, dan peredaran minuman beralkohol tidak memuaskan. Perda Jawa Timur Nomor 6 Tahun 2014 tersebut masih memerlukan perbaikan diberbagai aspek untuk dapat terakomodir nilai norma dan mewujudkan peraturan yang baik sesuai dengan nilai kebudayaan, moral, dan norma yang hidup di masyarakat.

Bagi para pakar hukum dan penggiat hukum, produk hukum bukanlah benda sakral yang tidak boleh dipertanyakan atau dipersoalkan lagi, semata-mata dengan alasan bahwa rancangan produk hukum sudah menjadi undang-undang. ${ }^{24}$ Dengan demikian layak jika seluruh elemen masyarakat tidak kecuali akademisi, terus

\footnotetext{
${ }^{23}$ Adre Ata Ujan, Filsafat Hukum, ( Yogyakarta : Kanisius, 2009), hlm 93.

${ }^{24}$ Satjipto Rahardjo, Biarkan Hukum Mengalir, (Jakarta : Kompas, 2008), hlm 2.
} 
melakukan kritik terhadap perda Jawa Timur Nomor 6 Tahun 2014. Sebab secara kajian akademik produk hukum tersebut disinyalir mengakomodir nilai dan norma yang hidup di masyarakat tidak sesuai dengan nilai dan norma masyarakat Indonesia.

Jika dilihat persoalan perda Jawa Timur Nomor 6 Tahun 2014 pada perspektif paradigma critical theory et al, maka dapat disimpulkan bahwa langkah pemerintah daerah Jawa Timur belum sepenuhnya dapat di benarkan, sebab belum dapat sepenuhnya mengakomodir realitas virtual yang terbentuk oleh faktor sosial, politik, budaya, nilai dan norma yang ada di Indonesia secara umum dan khususnya berada di Jawa Timur yang sudah mengkristal dan dianggap real.

Namun bagaimanapun juga, langkah pemerintah Jawa Timur tidak mutlak melakukan kesalahan. Patut diapresiasi juga langkah pemerintah daerah Jawa Timur yang telah membuat peraturan untuk membatasi peredaran minuman beralkohol secara bebas. Perlu diingat juga untuk menjadi konsideran bahwa Peraturan Presiden Nomor 74 Tahun 2013 juga tidak melarang sepenuhnya peredaran minuman beralkohol dan hanya mengatur peredarannya saja. Dengan begitu, harus diakui bahwa ada kendala bagi peraturan daerah untuk bertentangan dengan peraturan diatasnya atau dapat dikatakan mustahil karena bisa saja diuji materilkan. Namun, ada berita gembira akhirakhir ini yang menyatakan bahwa RUU Pelarangan Miras sudah di setujui oleh Rapat Paripurna DPR pada hari Selasa, 24 Juni 2014 yang mana RUU tersebut murni menjadi inisiatif DPR. Dengan demikian, diharapkan suatu hari nanti di Jawa Timur secara atau Indonesia dapat benar-benar bebas dari peredaran minuman beralkohol.

\section{REFERENSI}

Aji, RHS; \& Yunus, NR, Filsafat Manusia dalam Dimensi Transadental. Bogor: Pustaka Pena Ilahi, 2014

Indarti, Erlyn. Diskresi dan Paradigma : Sebuah Telaah Filsafat Hukum. Semarang : Badan Penerbit UNDIP. 2010

Scheltens, D.F. Pengantar Filsafat Hukum. Jakarta: Erlangga. 1984

Purnadi, P; Soerjono S. Renungan Tentang Filsafat Hukum. Jakarta: Rajawali. 1980

Rahardjo, Satjipto. Penegakan Hukum. Yogyakarta: Genta Publishing. 2009

Rahardjo, Satjipto. Ilmu Hukum. Bandung: Citra Aditya. 2000

Rasjidi, Lili. Dasar-Dasar Filsafat Hukum. Bandung: Alumni. 1982

Rhiti, Hyronimus. Filsafat Hukum. Yogyakarta: Univ Atma Jaya. 2011

Salman, Otje. Filsafat Hukum. Bandung: Refika Aditama. 2009

Soekanto, Soerjono. Hukum Adat Indonesia. Jakarta: Rajawali Press. 2011

Wignjosoebroto, Soetandyo. Pergeseran Paradigma dalam Kajian Sosial dan Hukum. Malang: Setara Press, 2013

Ujan, Adre A. Filsafat Hukum. Yogyakarta: Kanisius. 2009

http://www.jawapos.com/baca/artikel/4852/Perda-Miras-Akhirnya-Digedok 